\title{
Metal Nanoparticles-Mediated Changes on Gene Expressions and Physiological Parameters of Capsicum annuum L.
}

\author{
Metal Nanopartiküller Aracılığıyla, Capsicum annuum L.'nin Gen Ekspresyonu \\ ve Fizyolojik Parametreleri Üzerindeki Değişiklikler
}

\author{
Hülya Akdemir' ${ }^{1}$ (D) \\ 'Department of Molecular Biology and Genetics, Faculty of Science, Gebze Technical University, Kocaeli, Turkey
}

ORCID ID: H.A. 0000-0001-7923-3031

Cite this article as: Akdemir H. Metal nanoparticles-mediated changes on gene expressions and physiological parameters of Capsicum annuum L. Experimed 2021; 11(2): 88-95.

\begin{abstract}
Objective: The uptake and accumulation of nanoparticles by plants create a potential threat for human health in cases where humans consume the plants. The aim of the study was to analyze the potential beneficial or inhibitory effects of $\mathrm{nAl}_{2} \mathrm{O}_{3}$ and $\mathrm{nZnO}$ on Capsicum annuum L. (pepper)'s germination, root growth, and expression levels of aquaporin and dehydrin genes.
\end{abstract}

Material and Method: Different concentrations $(0.5,2.5$, or 5.0 $\mathrm{mM}$ ) of $\mathrm{nAl}_{2} \mathrm{O}_{3}$ and $\mathrm{nZnO}$ were used for the germination of pepper seeds. ICP-MS analysis was performed to determine ion contents in nanoparticle-treated pepper plants. Levels of aquaporin and dehydrin gene expressions were analyzed by quantitative reverse-transcription polymerase chain reaction (qRT-PCR).

Results: The pepper germination was not affected by nanoparticle applications. While $\mathrm{nAl}_{2} \mathrm{O}_{3}$ treatments did not change root growth, higher concentrations of $\mathrm{nZnO}$ negatively affected root length and root number. In particular, the application of $0.5 \mathrm{mM} \mathrm{nZnO}$ significantly upregulated aquaporin and dehydrin gene expressions in roots. Downregulation of dehydrin gene expression occurred in stems and roots after exposure to $\mathrm{nAl}_{2} \mathrm{O}_{3}$ treatments.

Conclusion: The gene expression alterations and changes of growth parameters showed especially $\mathrm{nZnO}$ have potentially phytotoxic for pepper plants. Moreover, expression analysis suggested that the tested genes may play roles in response to the nanoparticle-based abiotic stress.

Keywords: Aquaporin, dehydrin, nanoparticles, $\mathrm{nAl}_{2} \mathrm{O}_{3}, \mathrm{nZnO}$, germination, Capsicum annuum L., pepper

\section{öz}

Amaç: Nanopartiküllerin bitkiler tarafından alınması ve biriktirilmesi, bu bitkilerin insanlar tarafından tüketilmesi durumunda insan sağlığı için potansiyel bir tehdit oluşturmaktadır. Bu çalışmada, $\mathrm{nAl}_{2} \mathrm{O}_{3}$ ve $\mathrm{nZnO}$ 'nun Capsicum annuum L. (biber)'in çimlenmesi, kök büyümesi ile aquaporin ve dehidrin genlerinin ekspresyon seviyeleri üzerindeki potansiyel yararlı veya inhibe edici etkilerinin analiz edilmesi amaçlanmıştır.

Gereç ve Yöntem: Biber tohumlarının çimlenmesi için farklı konsantrasyonlarda $(0,5,2,5$ veya $5,0 \mathrm{mM}) \mathrm{nAl}_{2} \mathrm{O}_{3}$ ve $\mathrm{nZnO}$ kullanımıştır. Nanopartikül uygulanmış biber bitkilerinde iyon içeriklerini belirlemek için, ICP-MS analizi yapılmıştır. Aquaporin ve dehidrin gen ekspresyonlarının seviyeleri ise kantitatif ters transkripsiyon polimeraz zincir reaksiyonu (qRT-PCR) ile analiz edilmiştir.

Bulgular: Nanopartikül uygulamasının biber çimlenmesi üzerinde etkisi tespit edilmemiştir. $\mathrm{nAl}_{2} \mathrm{O}_{3}$ uygulamaları kök gelişimini değiştirmezken, yüksek nZnO konsantrasyonları kök uzunluğunu ve kök sayısını olumsuz yönde etkilemiştir. Köklerdeki aquaporin ve dehidrin gen ekspresyonu, özellikle 0,5 mM nZnO uygulaması ile artmıştır. $\mathrm{nAl}_{2} \mathrm{O}_{3}$ uygulanan kök ve gövdelerde ise dehidrin gen ekspresyonu azalmıştır.

Sonuç: Gen ekspresyon ve büyüme parametrelerindeki değişiklikler, özellikle nZnO'nun biber bitkileri için potansiyel olarak fitotoksik olduğunu göstermiştir. Ayrıca, ekspresyon analizi, test edilen genlerin nanopartikül bazlı abiyotik strese yanıt olarak rol oynayabileceğini önermektedir.

Anahtar Kelimeler: Aquaporin, dehydrin, nanopartikül, $\mathrm{nAl}_{2} \mathrm{O}_{3}$, $\mathrm{nZnO}$, çimlenme, Capsicum annuum L., biber 


\section{INTRODUCTION}

Engineered nanomaterials with their unique technical properties have extensive use in various technology and industrial sectors including mechanical industries, energy applications, environmental remediation, biosensing applications and many others (1).

Metal/metal oxide nanoparticles as engineered nanomaterials are synthesized by the addition of reducing agents to produce metal nanoparticles or oxidizing/precipitating agents for metal oxide nanoparticles (2). Because of the wide variety of applications of these nanoparticles in various industries, their effects on environment and several organisms including plants have been extensively studied (1).

Since the nanoparticles can contaminate plants in different stages of their life cycle (3), detailed studies should have been performed at molecular, cellular, metabolic, and physiological levels to comprehend the actual effects of metal oxide nanoparticles on plants. Analysis of their effects on seed germination and root elongation as a phytotoxicity parameter of these nanoparticles (4) have been studied in many plant species.

Assessment of changes on gene expression levels are another important parameter to obtain nanoparticle-based changes in plant body. Plants contain a large number of aquaporins, which are proteins responsible for controlling water transport and facilitating the transport of uncharged solutes across membranes (5). The importance of aquaporins has been demonstrated in various abiotic stress conditions (5) and alterations in their gene expressions following nanoparticle treatments were also obtained in plants (6). Even though their roles are not yet clearly understood, dehydrins are considered as stress proteins, which play a role in dehydration stress, and it is also suggested that some dehydrins may have critical roles in plant growth (7). It was demonstrated that expression levels of several genes such as aquaporins, oxidative response genes and housekeeping genes were affected by nanoparticle treatments $(8,9)$.

The uptake and accumulation of these nanoparticles by plants create a potential threat for human health in cases where humans consume the plants (10). Capsicum annuum L. (peppers) belong to the Solanaceae family and they are extensively consumed as both vegetables and spices across the world. Large areas of land in several countries such as Mexico, China, Korea, USA have been used for pepper cultivation because of their use in many cuisines (11). It suggests that there is possible nanoparticle contamination risk for these large land cultivation areas. In the study, pepper was used as a plant material because of its high consumption and production levels across the world and it was aimed to analyze potential beneficial or inhibitory effects of two metal oxide nanoparticles $\left(\mathrm{nAl}_{2} \mathrm{O}_{3}\right.$ and $\mathrm{nZnO}$ ) on its germination, root growth and expression levels of aquaporin (CaAqp) and dehydrin (CaDhn) genes.

\section{MATERIAL AND METHOD}

\section{Plant Material}

The pepper (Capsicum annuum L.) hybrid Bafra F1 seeds were used as a plant material. The seeds were gifted from Mehmet Yüksel, Yüksel Tohum (Antalya, Turkey) and kept in the dark at $4^{\circ} \mathrm{C}$ until use.

\section{Characterization of Nanoparticles}

The $\mathrm{nAl}_{2} \mathrm{O}_{3}$ (ca. $\left.40 \mathrm{~nm}\right)$ and $\mathrm{nZnO}(<100 \mathrm{~nm})$ nanopowders were purchased from PlasmaChem (Berlin, Germany) and Sigma Aldrich (Saint Louis, MO, USA), respectively. Although commercial manufacturers characterized the $\mathrm{nAl}_{2} \mathrm{O}_{3}$ and $\mathrm{nZnO}$ in detail, scanning electron microscope (SEM) and transmission electron microscope (TEM) were also used to visualize shape and morphology of the nanoparticles.

For SEM analysis, the nanoparticles were placed on a carbon disc and coated with a few $\mathrm{nm}$ thick gold-layers by using a Baltec SDC 005 sputter-coater. SEM images were obtained using a Carl Zeiss Evo ${ }^{\oplus} 40$ instrument under high vacuum with an accelerating voltage of $10 \mathrm{kV}$.

For TEM analysis, FEl Tecnai G2 Spirit BioTwin CTEM instrument operating at an accelerating voltage of $120 \mathrm{kV}$ were used.

\section{Medium Preparation}

Murashige and Skoog (MS) basal medium were purchased from Sigma Aldrich (Saint Louis, MO, USA). 0.5, 2.5 and $5 \mathrm{mM}$ of $\mathrm{nAl}_{2} \mathrm{O}_{3}$ and $\mathrm{nZnO}$ were used to test their effects on pepper plants. Firstly, nanopowders were suspended in half strength MS medium ( $\mathrm{pH}: 6.0$ ) by sonication for $30 \mathrm{~min}$ in ultrasonic water bath at room temperature, and then the suspensions were homogenized by stirring them for $20 \mathrm{~min}$ before use.

\section{Plant germination and seedling establishment}

The pepper seeds were imbibed with distilled water for 16 hours before treatments. Then, the seeds were transferred to $900 \mathrm{~cm}^{3}$ vitrovents (Duchefa, The Netherlands) including 1 layer of sterile damp filter paper moistened with $5 \mathrm{~mL}$ of sterile one-half-MS medium ( $\mathrm{pH}: 6.0)$ containing $0.5,2.5$ and $5 \mathrm{mM} \mathrm{nAl}_{2} \mathrm{O}_{3}$ or $\mathrm{nZnO}$. For the control group, the seeds were transferred to the vitrovents including 1 layer of sterile damp filter paper moistened with $5 \mathrm{~mL}$ of sterile half strength MS medium without any of nanoparticles. Then, the vitrovents were incubated at $24^{\circ} \mathrm{C}$ for the first 7 days in the dark and then 8 days in the light. Each vitrovent containing 10 seeds per control group and nanoparticles treatments were used and each treatment was replicated three times.

\section{Germination Data Analysis}

The germination percentages, root number, length of roots and leaves of the control and nanoparticles-treated plants were obtained at the end of the $15^{\text {th }}$ day of Capsicum seeds. SPSS version 25 (SPSS, USA) was used to perform statistical analysis. Germination percentages were analyzed with Chisquare statistics. One-way ANOVA (Analysis of variance) was performed to compare mean differences of leaf length. Root 
length data were subjected to ANOVA, followed by Tukey posthoc test to compare mean values. Because root number values do not have a normal distribution, the data were analyzed with the Kruskal-Wallis test, followed by the Mann-Whitney $\mathrm{U}$ test as a post hoc test. $p \leq 0.05$ was used as the level of significance for all the statistical analyses.

\section{Gene expression analysis of Capsicum annuum L. genes}

Quantitative reverse-transcription polymerase chain reaction (qRT-PCR) was used to obtain impacts of $\mathrm{nAl}_{2} \mathrm{O}_{3}$ and $\mathrm{nZnO}$ on the expression levels of genes, CaDhn (Accesion no. AY225438.1) and CaAqp2 (CaTIP1;1, Accession no. GU116569). Firstly, total RNA was extracted from the 15-day-old stems and 15-day-old roots of the peppers using the Plant/Fungi Total RNA purification kit (Norgen Biotek) according to the manufacturer's instructions, with DNasel treatment (DNase I, RNasefree, NEB). The RNA quantification was performed using Nanodrop equipment (Thermo Scientific Nanodrop ${ }^{\mathrm{TM}}$ 2000) and RNA samples were visualized by running them in $1.5 \%$ agarose gel with $\mathrm{EtBr}$ to check their integrity. Secondly, CDNA templates were reverse transcribed from purified RNA samples $(3 \mu \mathrm{g}$ per treatment) using SuperScript ${ }^{\mathrm{TM}}$ IV First-Strand Synthesis System (Invitrogen ${ }^{\mathrm{TM}}$ ) according to manufacturer's instructions. The obtained cDNAs were kept at $-20^{\circ} \mathrm{C}$ until use in qRT-PCR. The NCBI database (https://www.ncbi.nlm.nih.gov/) and its BLAST tool (blast.ncbi.nlm.nih.gov) were used to get full-length sequences and verification of mRNA sequences of $\mathrm{CaDhn}$ and CaAqp2 genes, respectively. All gene-specific qRT-PCR primers from mRNA sequences were designed by Primer3 v4.1.0 (12).

The housekeeping genes, Actin mRNA, GapdH (glyceraldehyde 3-phosphate dehydrogenase GapCp) and EIF5A2 (Eukaryotic translation initiation factor 5A2) were used for normalization and their primer sequences were obtained from Wan et al. (13).

The primers used in the present study are listed below $\left(5^{\prime}-3^{\prime}\right)$ :

Actin mRNA (F; TGTTATGGTAGGGATGGGTC, R; TTCTCTCTATTTGCCTTGGG),

GapdH (F; ATGATGATGTGAAAGCAGCG, R; TTTCAACTGGTGGCTGCTAC),

EIF5A2 (F; CCTGTTATCGTGCTACTTTG, R; GTTTCATTGCCKTGCCAGAT)

CaAqp2 (F; CGATGGCGTCACTACTCCTC, R; CACCAACGAAAGCACCGA)

CaDhn (F; GGAGAAATTGCCAGGGTATCACTC, R; CAGAACACCACAATCATAACATACC)

qRT-PCR analysis was carried as three replicates. Reactions (10 $\mu \mathrm{L})$ contain template CDNA $(1 \mu \mathrm{L})$, Biorad iTaq Universal SYBR Green Supermix $(5 \mu \mathrm{L})$, reverse $(4 \mu \mathrm{M})$ and forward $(4 \mu \mathrm{M})$ primers and nuclease-free water. CFX96 Touch Real Time PCR instrument (Biorad, France) was used for qRT-PCR analysis and the analysis conditions were $3 \mathrm{~min}$ at $95^{\circ} \mathrm{C}$ followed by 40 cycles of $5 \mathrm{sec}$ at $95^{\circ} \mathrm{C}$ and $30 \mathrm{sec}$ at $60^{\circ} \mathrm{C}$.

Melt curve analysis was performed following each qRT-PCR amplification by heating the product from $65^{\circ} \mathrm{C}$ to $95^{\circ} \mathrm{C}, 0.5^{\circ} \mathrm{C}$ in 5 $\mathrm{s}$ increments. The optimal cycle threshold (Ct) was determined using Biorad CFX Manager 3.1 software. The above-men- tioned housekeeping genes were used for normalization using GeNorm V3 algorithm (14). The obtained normalized $c_{q}$ values were processed according to the $\Delta \Delta c_{q}$ method and presented as relative expression values for each gene.

\section{Determination of ion content}

Inductively coupled plasma mass spectrometry (ICP-MS, Thermo ICP MS X Series 2) was used to determine the level of aluminum and zinc ion contents of $\mathrm{nAl}_{2} \mathrm{O}_{3}$ or $\mathrm{nZnO}$ treated pepper plants. The control and nanoparticles-treated plant samples (ca. $0.1 \mathrm{~g}$ ) were weighted and digested with a $6 \mathrm{~mL} 65 \%(\mathrm{v} / \mathrm{v})$ nitric acid. Following incubation in an ultrasonic water bath for $15 \mathrm{~min}$, the samples were kept at room temperature for $24 \mathrm{~h}$ to complete the extraction. One-way ANOVA was performed to compare mean differences of ion contents in nanoparticles-treated plants.

Dissolution of $\mathrm{Al}^{3+}$ and $\mathrm{Zn}^{2+}$ ions in the exposure medium was obtained according to Leclerc and Wilkinson (15):

1. Centrifugation of the medium at $2500 \times \mathrm{xg}$ using centrifugation tubes containing $3 \mathrm{kDa}$ centrifugal ultrafiltration unit (Merck Millipore, Germany) for 15 min at 0., 1., and 7. day.

2. Repetition of the $1^{\text {st }}$ step four times and collecting only the filtrate at each centrifugation step.

3. Addition of $2 \%$ nitric acid to the $1 \mathrm{~mL}$ of filtrate.

4. ICP-MS analysis was evaluated to measure the release rates of $\mathrm{Al}^{3+}$ and $\mathrm{Zn}^{2+}$ from $\mathrm{nAl}_{2} \mathrm{O}_{3}$ or $\mathrm{nZnO}$.

For all ICP-MS analysis, multi-element ICP QC Standard solution (Chem-Lab, Belgium) was used as ICP-MS standard.

\section{RESULTS}

\section{Characterization of Nanoparticles}

SEM (Figure 1A-1B) and TEM (Figure 1C-1D) analysis were performed to visualize the shape and size of the tested nanopar-
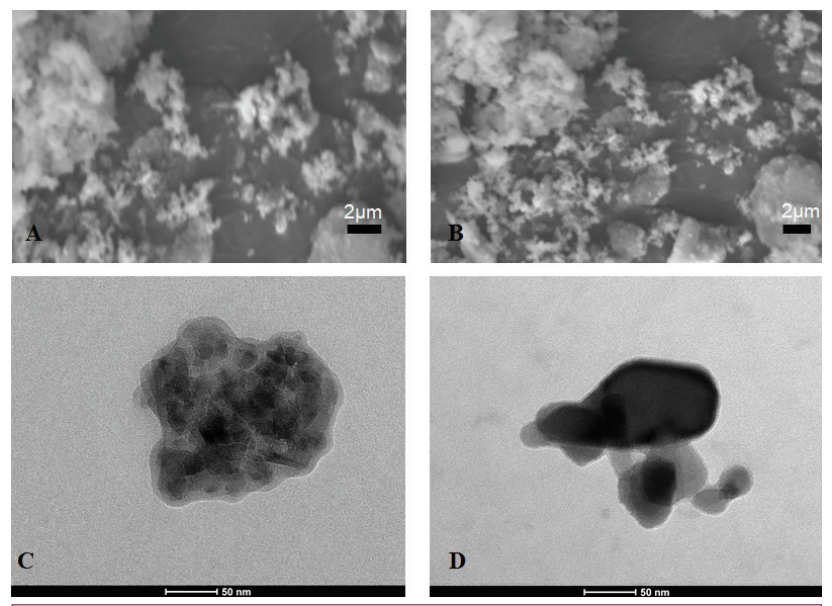

Figure 1. Images of the $\mathrm{nAl}_{2} \mathrm{O}_{3}(\mathrm{~A}, \mathrm{SEM} ; \mathrm{C}, \mathrm{TEM})$ and $\mathrm{nZnO}$ (B, SEM; D, TEM). 
ticles. The images demonstrated the presence of uneven size with irregular, elongated, spherical shaped nanoparticles. While TEM analysis clearly showed that $\mathrm{nZnO}$ has different sizes from $40 \mathrm{~nm}$ to $100 \mathrm{~nm}$, the $\mathrm{nAl}_{2} \mathrm{O}_{3}$ images were very low-resolution so it was not possible to obtain their mean sizes.

\section{Effects of $\mathrm{nAl}_{2} \mathrm{O}_{3}$ and $\mathrm{nZnO}$ on the germination parameters of pepper}

The effects of different $\mathrm{nAl}_{2} \mathrm{O}_{3}$ and $\mathrm{nZnO}$ concentrations (0.5, 2.5 and $5 \mathrm{mM}$ ) on pepper germination were analyzed and the germination percentages are presented in Figure 2. The results showed that the germination percentages of pepper seeds germinated in the MS medium at those nanoparticles concentrations were not statistically different in comparison to the control group seeds, which were germinated in the medium without nanoparticles.

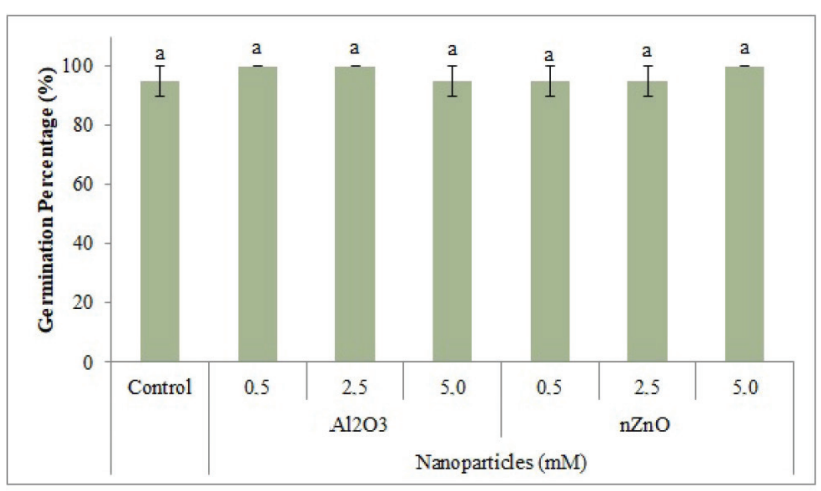

Figure 2. Germination percentages of $\mathrm{nAl}_{2} \mathrm{O}_{3}$ and $\mathrm{ZnO}$ treated pepper seeds.
The average length of root and leaf of pepper plants were recorded and the results are presented in Table 1. Even though the longest leaves $(60.8 \mathrm{~mm})$ were obtained in the control and $2.5 \mathrm{mM} \mathrm{nAl}_{2} \mathrm{O}_{3}$-treated pepper plants, there were no statistically significant differences among the tested plants.

While the control and $\mathrm{nAl}_{2} \mathrm{O}_{3}$-treated pepper plants had statistically similar root lengths, the application of $\mathrm{nZnO}$ at different concentrations affected root length compared to control plants. The longest roots $(36.2 \mathrm{~mm})$ and the shortest roots $(14.7$ $\mathrm{mm}$ ) were obtained with the application of the lowest and highest $\mathrm{nZnO}$ concentrations, respectively.

Regarding number of roots, similar effects were observed with the application of $\mathrm{nZnO}$ at the end of the $15^{\text {th }}$ day (Table 2). Even though a statistically similar number of roots were obtained in the control and $\mathrm{nAl}_{2} \mathrm{O}_{3}$-treated pepper plants, higher $\mathrm{nZnO}$ concentrations had adverse effects on the number of roots. The decreased root numbers (1.11 and 1.00) were obtained with the application of 0.25 and $0.5 \mathrm{mM} \mathrm{nZnO}$ concentrations (Table 2).

\section{Determination of ion content}

To understand the detailed impacts of applied metal nanoparticles on pepper plants, ICP-MS analysis was performed to obtain $\mathrm{Al}^{3+}$ and $\mathrm{Zn}^{2+}$ ions in pepper stems and roots following $\mathrm{nAl}_{2} \mathrm{O}_{3}$ and $\mathrm{nZnO}$ treatments. Interestingly, $\mathrm{Al}^{3+}$ ions were not detected in $\mathrm{nAl}_{2} \mathrm{O}_{3}$-treated pepper stems and roots with ICPMS analysis. ICP-MS analysis showed the presence of $\mathrm{Zn}^{2+}$ ions in both pepper stems and roots with the application of $\mathrm{nZnO}$ in MS medium (Table 3). An accumulation of $\mathrm{Zn}^{2+}$ ions [44.3 and $70.4 \mathrm{mg} / \mathrm{kg} \mathrm{FW}$ (fresh weight)] was found in $0.5 \mathrm{mM}$ and 2.5 $\mathrm{mMnZnO}$ applied stems, respectively. The higher levels of $\mathrm{Zn}^{2+}$ ions were determined in the $0.5 \mathrm{mM}(312.4 \mathrm{mg} / \mathrm{kg} \mathrm{FW})$ and 2.5

Table 1. Root and leaf length of control and nanoparticles-treated pepper plants.

\begin{tabular}{|c|c|c|c|}
\hline Nanoparticles & Concentration (mM) & Average root length $(\mathrm{mm}) *$ & Average leaf length $(\mathrm{mm}) *$ \\
\hline Control & 0 & $29.1 \pm 1.59 b$ & $60.8 \pm 1.57 a$ \\
\hline \multirow{3}{*}{$\mathrm{Al}_{2} \mathrm{O}_{3}$} & 0.5 & $26.8 \pm 1.48 b$ & $59.4 \pm 3.03 a$ \\
\hline & 2.5 & $27.5 \pm 1.89 b$ & $60.8 \pm 1.66 a$ \\
\hline & 5.0 & $29.4 \pm 1.78 a b$ & $59.4 \pm 2.01 a$ \\
\hline \multirow{3}{*}{ ZnO } & 0.5 & $36.2 \pm 1.97 a$ & $55.5 \pm 2.56 a$ \\
\hline & 2.5 & $22.7 \pm 1.31 b c$ & $57.0 \pm 2.27 a$ \\
\hline & 5.0 & $14.7 \pm 0.88 d$ & $55.2 \pm 2.06 a$ \\
\hline & \multirow{2}{*}{ Significance test } & $F=13.830$ & $F=1.079$ \\
\hline & & $p=0.000$ & $p=0.383$ \\
\hline & Statistical Analysis Test & One-way ANOVA Tukey & One-way ANOVA \\
\hline
\end{tabular}

* Values were represented as mean $\pm \mathrm{SE}$.

The different letters following the means in each column show statistical differences at $\mathrm{p} \leq 0.05$ according to ANOVA Test. The mean differences were analyzed vertically. 
Table 2. The impacts of $\mathrm{nAl}_{2} \mathrm{O}_{3}$ and $\mathrm{nZnO}$ on root numbers of pepper plants ${ }^{\mathrm{a}}$.

\begin{tabular}{|c|c|c|c|c|}
\hline \multirow[b]{2}{*}{ Nanoparticles } & \multirow[b]{2}{*}{ Concentration (mM) } & \multicolumn{3}{|c|}{ Kruskal-Wallis Test } \\
\hline & & Number of roots ${ }^{b}$ & Mean rank & Significance test \\
\hline \multirow[t]{2}{*}{ Control } & 0 & $1.84 \pm 0.27$ & 78.53 & \multirow{7}{*}{$\begin{array}{c}x^{2}=20.037 \\
\mathrm{df}=6 \\
p=0.003\end{array}$} \\
\hline & 0.5 & $1.85 \pm 0.24$ & 79.83 & \\
\hline \multirow[t]{3}{*}{$\mathrm{Al}_{2} \mathrm{O}_{3}$} & 2.5 & $2.15 \pm 0.33$ & 82.93 & \\
\hline & 5.0 & $1.37 \pm 0.17$ & 63.61 & \\
\hline & 0.5 & $1.58 \pm 0.25$ & 68.50 & \\
\hline \multirow[t]{2}{*}{ Zno } & 2.5 & $1.11 \pm 0.07^{*}$ & 55.74 & \\
\hline & 5.0 & $1.00 \pm 0.00^{*}$ & 50.00 & \\
\hline $\begin{array}{l}\text { 'Root number values } \\
{ }^{b} \text { Values were represe }\end{array}$ & $\begin{array}{l}\text { ted groups were individually c } \\
\text { ean } \pm \text { SE. }\end{array}$ & oared with each other by $u$ & nn-Whitney U nor & \\
\hline \multicolumn{5}{|c|}{ *Values were significantly different $(p \leq 0.05)$} \\
\hline
\end{tabular}

mM (933.5 mg/kg FW) nZnO-applied pepper roots. However, no statistical differences were detected in the content of $\mathrm{Zn}^{2+}$ ions between control and $5 \mathrm{mM} \mathrm{nZnO-applied} \mathrm{pepper} \mathrm{stems}$ and roots (Table 3 ).

Table 3. $\mathrm{Zn}^{2+}$ content of pepper stems and roots treated with $\mathrm{nZnO}$.

\begin{tabular}{lcc}
\hline & \multicolumn{2}{c}{$\mathbf{Z n}^{2+}$ content $(\mathbf{m g} / \mathbf{k g ~ F W})$} \\
\cline { 2 - 3 } Concentration (mM) & Stem* & Root* \\
\hline 0 (Control) & $2.21 \pm 0.06 \mathrm{c}$ & $4.27 \pm 0.07 \mathrm{c}$ \\
\hline 0.5 & $44.32 \pm 0.19 \mathrm{~b}$ & $312.44 \pm 1.16 \mathrm{~b}$ \\
\hline 2.5 & $70.39 \pm 0.60 \mathrm{a}$ & $933.49 \pm 3.61 \mathrm{a}$ \\
\hline 5.0 & $2.81 \pm 0.13 \mathrm{c}$ & $4.68 \pm 0.02 \mathrm{c}$ \\
\hline * Values were represented as mean \pm SE. & \\
$\begin{array}{l}\text { The different letters following the means in each column show statistical } \\
\text { differences at } \mathrm{p} \leq 0.05 \text { according to ANOVA Test. }\end{array}$ \\
\hline
\end{tabular}

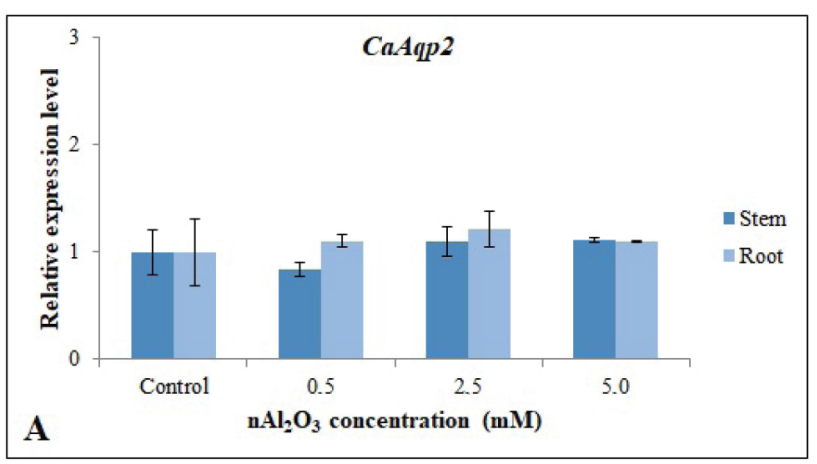

ICP-MS analysis was performed to obtain the release rates of dissolved $\mathrm{Al}^{3+}$ and $\mathrm{Zn}^{2+}$ ions from $\mathrm{nAl}_{2} \mathrm{O}_{3}$ and $\mathrm{nZnO}$ containing MS media in $1^{\text {st }}$ and $7^{\text {th }}$ day. The results showed that the dissolution of $\mathrm{Al}^{3+}$ and $\mathrm{Zn}^{2+}$ ions from the applied nanoparticles was very low (Table 4). While $\mathrm{Al}^{3+}$ release from $\mathrm{nAl}_{2} \mathrm{O}_{3}$ was only $0.053 \%, \mathrm{Zn}^{2+}$ release from $\mathrm{nZnO}$ was $0.153 \%$ even after 7 days (Table 4 ).

Table 4. The percentages (\%) of $\mathrm{Al}^{3+}$ and $\mathrm{Zn}^{2+}$ released from $2.5 \mathrm{mM} \mathrm{nAl}_{2} \mathrm{O}_{3}$ or $\mathrm{nZnO}$ containing culture medium.

\begin{tabular}{lcc}
\hline Duration (days) & $\mathbf{A l}^{3+}$ release (\%) & $\mathbf{Z n}^{2+}$ release (\%) \\
\hline $\mathbf{0}$ & - & - \\
\hline $\mathbf{1}$ & 0.028 & 0.069 \\
\hline $\mathbf{7}$ & 0.053 & 0.153 \\
\hline
\end{tabular}

\section{qRT-PCR analysis of CaAqp2 and CaDhn genes}

To understand the effects of the tested metal nanoparticles at the molecular level, relative expression levels of two pepper genes (CaAqp2 and CaDhn) were analyzed by qRT-PCR (Figure 3 and

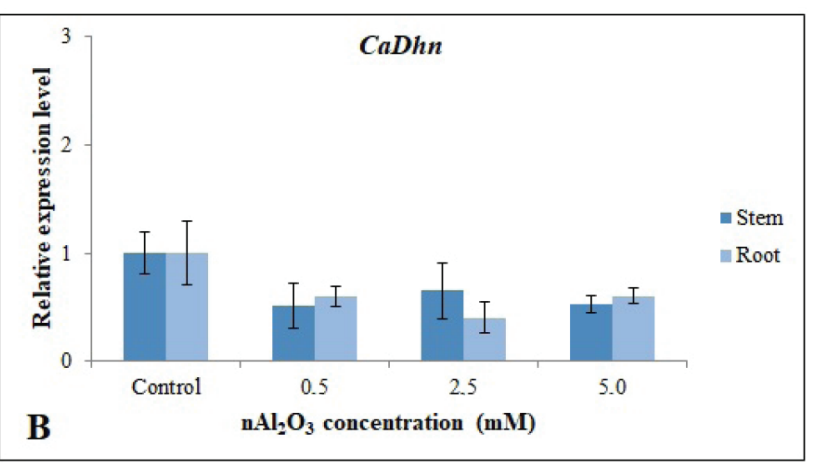

Figure 3. Relative expression levels of CaAqp2 and CaDhn in $\mathrm{nAl}_{2} \mathrm{O}_{3}$-treated pepper plants. 

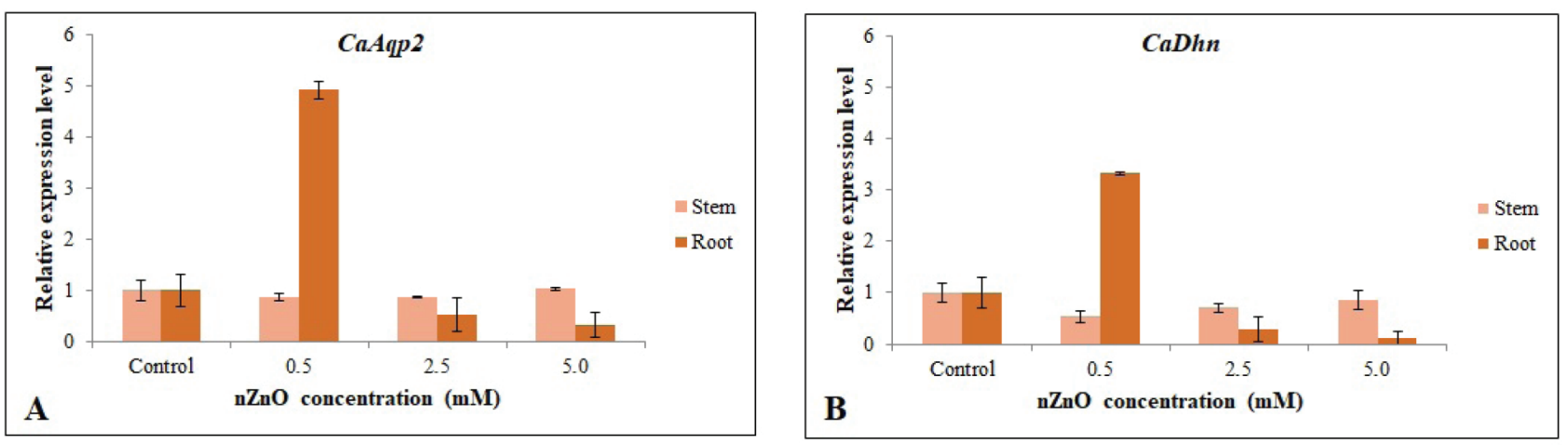

Figure 4. Relative expression levels of CaAqp2 and CaDhn in nZnO-treated pepper plants.

Figure 4). Application of $\mathrm{nAl}_{2} \mathrm{O}_{3}$ did not have a significant effect on the relative expression of CaAqp2 in stems and roots (Figure $3 \mathrm{~A})$. The only decrease in gene expression levels was obtained in stems of $0.5 \mathrm{mM} \mathrm{nAl}_{2} \mathrm{O}_{3}$-treated pepper plants. Application of 2.5 and $5 \mathrm{mM} \mathrm{nAl}_{2} \mathrm{O}_{3}$ led to a slight increase of CaAqp2 in stems and roots. On the other hand, $\mathrm{nAl}_{2} \mathrm{O}_{3}$ treatments inhibited $\mathrm{CaDhn}$ gene expression in stems and roots with respect to the control groups (Figure 3B). 0.5 and $5 \mathrm{mM} \mathrm{nAl}_{2} \mathrm{O}_{3}$ treatments resulted in statistically similar gene expression levels in stems and roots. 2.5 $\mathrm{mM} \mathrm{nAl} \mathrm{O}_{3}$ treatments upregulated $\mathrm{CaDhn}$ gene expression in stems compared to the other applied concentrations.

The CaAqp2 and CaDhn expression levels of pepper plants were strongly affected by $\mathrm{nZnO}$ treatments (Figure $4 \mathrm{~A}$ and $4 \mathrm{~B}$ ). The highest CaAqp2 expression (almost five times higher expression than that of control) was obtained in the roots of $0.5 \mathrm{mM}$ nZnO-treated pepper plants (Figure 4A). Increased concentrations of $\mathrm{nZnO}$ applications resulted in inhibition of CaAqp2 expression in roots. While CaAqp2 expression levels showed a slight decrease in lower concentrations of $\mathrm{nZnO}$ applications in stems, the highest $\mathrm{nZnO}$ concentration $(5 \mathrm{mM})$ resulted in similar gene expression levels when compared to the control group (Figure 4A). CaDhn gene expression in roots was significantly affected with the application of $0.5 \mathrm{mM} \mathrm{nZnO}$ (Figure $4 \mathrm{~B})$. Its expression was three-times higher than that of the control roots. However, higher $\mathrm{nZnO}$ treatments dramatically decreased CaDhn gene expression levels in roots. $\mathrm{nZnO}$-applied pepper plants had lower gene expression of CaDhn in stems with respect to the control group (Figure 4B).

\section{DISCUSSION}

An increase in the worldwide use of engineered metal nanoparticles is predicted to result in an elevated transfer of these particles to the environment. The studies and modeling analysis showed that thousands of tons of nanoparticles including $\mathrm{Al}$, $\mathrm{Zn}, \mathrm{Ag}$, Fe etc. have been released into the environment due to their extensive production (16). The studies demonstrated their toxic and sometimes promoting effects in various plant growth parameters. Being one of the most consumed vegetables, the contamination of pepper production areas with these nanoparticles is highly possible. Among these nanoparticles,
$\mathrm{nZnO}$ and $\mathrm{nAl}_{2} \mathrm{O}_{3}$ are the metal oxides and they have a wide application from electronics to biomedical applications and many others $(17,18)$. In the present study, the impacts of $\mathrm{nAl}_{2} \mathrm{O}_{3}$ (ca. $40 \mathrm{~nm})$ and $\mathrm{nZnO}(<100 \mathrm{~nm})$ metal oxide nanoparticles were tested on pepper germination and seedling establishment parameters. The results showed that germination of pepper seeds was not affected with treatments of different concentrations of $\mathrm{nZnO}$ and $\mathrm{nAl}_{2} \mathrm{O}_{3}$. Similarly, Cucurbita pepo (zucchini) germination was unaffected by the treatment of $1000 \mathrm{mg} / \mathrm{L} \mathrm{nZnO}(<5$ $\mathrm{nm}$ and $<10 \mathrm{~nm}$ ) (19). Kumar et al. (20) tested the impacts of $\mathrm{nZnO}(\leq 50 \mathrm{~nm})$ on several plant species and reported its inhibitory effects on cucumber germination and on shoot and root growth of wheat, green gram and cucumber. However, germination of rice was not significantly inhibited by the nanoparticles. Lee et al. (21) tested the effects of various metal oxide nanoparticles including $\mathrm{nAl}_{2} \mathrm{O}_{3}, \mathrm{nSiO}_{2}, \mathrm{nFe}_{3} \mathrm{O}_{4}$ and $\mathrm{nZnO}$ on seed germination and root elongation of Arabidopsis thaliana. The results showed that while $\mathrm{nZnO}$ was the most phytotoxic, $\mathrm{nAl}_{2} \mathrm{O}_{3}$ was not toxic for these plants. Regarding root length and number, none of the concentrations of $\mathrm{nAl}_{2} \mathrm{O}_{3}$ used affected root growth of peppers. While the lowest concentration of $\mathrm{nZnO}$ treatments increased average root length, the highest levels of $\mathrm{nZnO}$ decreased root length compared to the control plants in this study. Higher nZnO concentrations also negatively affected the number of roots. Similarly, an increased root length in rice was obtained when the seeds were soaked in $<100 \mathrm{mg} / \mathrm{L} \mathrm{nZnO}$ solution for 1-2 days, but the root growth was dramatically inhibited at concentrations of 500 and $1000 \mathrm{mg} / \mathrm{L}$ $\mathrm{ZnO}$ (22). Similar to the shortest roots resulting from high $\mathrm{nZnO}$ concentrations, the application of higher $\mathrm{nZnO}$ concentrations also resulted in reduced root length in barley (23).

The studies show that the size, concentration, composition, physical and chemical properties determine the fate of these nanoparticles on plants (24). The plant cell walls have a size exclusion limit ( 5-20 nm) (25). However, some nanoparticles such as silver nanoparticles in Chlamydomonas reinhardtii (26) led to the formation of bigger pores in the cell walls and thereby resulted in the entrance of larger particles. Root junction, wounding, endocytosis, and symplastic transport could be other ways to accumulate or transport the nanoparticles in the 
plant body (1). Moreover, plants can accumulate nanoparticles directly or as metal ions (27). In the present study, no $\mathrm{Al}^{3+}$ ions were detected in $\mathrm{nAl}_{2} \mathrm{O}_{3}$-treated pepper stems and roots with ICP-MS analysis. The results suggested that the ion content was probably out of detection limits. However, the increased $Z^{2+}$ contents in pepper stems and especially in the roots suggested that even though the $\mathrm{nZnO}$ used in the present study is much bigger than the size limit for the plant cell wall, their uptake from shoots and roots could be acquired by one of above-mentioned mechanisms. The very low rates of dissolution of these ions from exposure to medium demonstrate that any obtained effects in pepper plants could be due to the direct uptake of these nanoparticles instead of their released ions. It can be concluded that the obtained effects on root length and root numbers of $\mathrm{nZnO}$-treated plants were probably due to the high uptake of nanoparticles and accumulation in roots and stems.

Plants have complex response and defense mechanisms to adapt to different stress conditions (28). The effects of nanoparticles could be also obtained at the level of gene expression. In the present study, relative expression levels of CaAqp $(\mathrm{CaTIP1} ; 1)$ from the tonoplast intrinsic proteins subfamily and $\mathrm{CaDhn}$ were investigated in 15-day-old pepper seedlings after exposure to $\mathrm{nAl}_{2} \mathrm{O}_{3}$ and $\mathrm{nZnO}$.

Dehydrins are considered as stress proteins, and they play role in drought stress tolerance (7). They also have other functions such as binding metal ions, binding DNA, binding phospholipids and they can scavenge free radicals (7). Downregulation of $\mathrm{CaDhn}$ was observed in stems and roots following $\mathrm{nAl}_{2} \mathrm{O}_{3}$ and $\mathrm{nZnO}$ treatments. Upregulation of CaDhn was only observed with lowest levels of $\mathrm{nZnO}$ treatments in stems. The altered gene expression in stems and roots profiles indicates that this gene may have a function in metal oxide nanoparticle-based stress tolerance. In addition to their functions in water movement across cell membranes, aquaporins also have roles in response to the biotic and abiotic stress. The adverse effects of changes in aquaporin expression may especially be observed during germination and seedling development. However, $\mathrm{nAl}_{2} \mathrm{O}_{3}$ treatments did not significantly affect the investigated aquaporin gene expressions in pepper stems and roots. On the other hand, while $\mathrm{nZnO}$ treatments at $0.5 \mathrm{mM}$ concentration led to an upregulation of CaAqp2 in root tissues, higher levels of $\mathrm{nZnO}$ resulted in a downregulation of the gene in those tissues. Since roots are the first target for nanoparticles, alterations in gene expression might occur more often than expected in roots. It could be the reason for the critical alterations of gene expression in roots compared to that of stems. Aquaporin genes were significantly activated in tomato roots by carbon nanotubes treatments (29). The same increase was also observed in Arabidopsis plants after 1 week of exposure to Ag nanoparticles, but their levels decreased with prolonged exposure times (6). The altered CaAqp2 expressions in the present study indicate that these nanoparticles affected plant's water and small molecules homeostasis following nZnO treatments. A slight decrease of aquaporin genes was also observed in pepper stems in nZnO applications. Gitto and Fricke (30) showed that the decrease in expression of certain barley aquaporin genes was stronger with lower $\mathrm{Zn}$ treatments than higher $\mathrm{Zn}$ treatments. It is concluded that plants would have limited $\mathrm{Zn}$ transport to the shoot to prevent major toxicity (30).

\section{CONCLUSION}

The extensive use of metal nanoparticles worldwide is predicted to result in an elevated transfer of these particles to the environment. In the present study, the impacts of $\mathrm{nAl}_{2} \mathrm{O}_{3}$ and $\mathrm{nZnO}$ on pepper germination, root growth and gene expression levels were analyzed. The results showed that pepper germination was not affected by nanoparticles applications. While $\mathrm{nAl}_{2} \mathrm{O}_{3}$ treatments did not significantly change root growth, higher concentrations of $\mathrm{nZnO}$ negatively affected root length and root number. In particular, the application of $0.5 \mathrm{mM} \mathrm{nZnO}$ upregulated aquaporin and dehydrin gene expressions in roots, significantly. Downregulation of dehydrin gene expression was obtained in stems and roots after exposure to $\mathrm{nAl}_{2} \mathrm{O}_{3}$ treatments. These gene expression alterations and changes of growth parameters showed that $\mathrm{nZnO}$ especially is potentially phytotoxic for pepper plants. Moreover, expression analysis suggested that the tested genes may play roles in response to the nanoparticle based abiotic stress.

Acknowledgments: The author would like to thank Dr. Merve Seven for technical help in the gene expression analysis, Dr. Şaban Kalay for carrying out SEM analysis and Şahin Yılmaz for helping with ICP-MS analysis.

Ethics Committee Approval: Ethics committee approval is not required because of no material or experimental animal that would require permission.

Peer-review: Externally peer-reviewed.

Financial Disclosure: The author declared that this study has received no financial support.

Teşekkür: Yazar, gen ekspresyon analizindeki teknik yardım için Dr. Merve Seven'e, SEM analizini gerçekleştiren Dr. Şaban Kalay'a ve ICPMS analizine yardımcı olduğu için Şahin Yılmaz'a teşekkür eder.

Etik Komite Onayı: Bu çalışmada, etik komite iznine gerek duyulacak bir materyal ya da deney hayvanı kullanılmamıştır.

Hakem Değerlendirmesi: Dış bağımsız.

Finansal Destek: Yazarlar bu çalışmada finansal destek almadıklarını beyan etmişlerdir.

\section{REFERENCES}

1. Rastogi A, Zivcak M, Sytar O, Kalaji HM, He X, Mbarki S, et al. Impact of metal and metal oxide nanoparticles on plant: A critical review. Front Chem 2017; 5: 78. [CrossRef]

2. Sanchez-Dominguez $M$, Boutonnet $M$, Solans $C$. A novel approach to metal and metal oxide nanoparticle synthesis: the oilin-water microemulsion reaction method. J Nanopart Res 2009; 11:1823. [CrossRef] 
3. Du W, Yang J, Peng Q, Liang X, Mao H. Comparison study of zinc nanoparticles and zinc sulphate on wheat growth: From toxicity and zinc biofortification. Chemosphere 2019; 227:109-116. [CrossRef]

4. Dogaroglu ZG, Koleli $\mathrm{N}$. $\mathrm{TiO}_{2}$ and $\mathrm{ZnO}$ nanoparticles toxicity in barley (Hordeum vulgare L.) CLEAN Soil, Air, Water 2017; 45(11): 1700096 (1-7). [CrossRef]

5. Afzal Z, Howton TC, Sun Y, Mukhtar MS. The Roles of Aquaporins in Plant Stress Responses. J Dev Biol 2016; 4(1):9. [CrossRef]

6. Qian H, Peng X, Han X, Ren J, Sun L, Fu Z. Comparison of the toxicity of silver nanoparticles and silver ions on the growth of terrestrial plant model Arabidopsis thaliana. J Environ Sci 2013; 25, 1947-1955. [CrossRef]

7. Liu Y, Song Q, Li D, Yang X and Li D. Multifunctional roles of plant dehydrins in response to environmental stresses. Front Plant Sci 2017; 8: 1018. [CrossRef]

8. Nair PM, Chung IM. Impact of copper oxide nanoparticles exposure on Arabidopsis thaliana growth, root system development, root lignificaion, and molecular level changes. Environ Sci Pollut Res Int 2014; 21: 12709-22. [CrossRef]

9. Selvakesavan RK, Franklin G. Nanoparticles affect the expression stability of housekeeping genes in plant cells. Nanotechnol Sci Appl 2020; 13: 77-88. [CrossRef]

10. Ma X, Yan J. Plant uptake and accumulation of engineered metallic nanoparticles from lab to field conditions. Curr Opin Environ Sci Health 2018; 6: 16-20. [CrossRef]

11. Olatunji TL, Afolayan AJ. The suitability of chili pepper (Capsicum annuum L.) for alleviating human micronutrient dietary deficiencies: A review. Food Sci Nutr 2018; 6(8): 2239-51. [CrossRef]

12. Untergasser A, Cutcutache I, Koressaar T, Ye J, Faircloth BC, Remm $M$, et al. Primer3-New Capabilities and Interfaces. Nucleic Acids Res 2012; 40(15): e115. [CrossRef]

13. Wan H, Yuan W, Ruan M, Ye Q, Wang R, Li Z, et al. Identification of reference genes for reverse transcription quantitative real-time PCR normalization in pepper (Capsicum annuum L.). Biochem Biophys Res Commun 2011; 416(1-2): 24-30. [CrossRef]

14. Vandesompele J, De Preter K, Pattyn F, Poppe B, Van Roy N, De Paepe $A$, et al. Accurate normalization of real-time quantitative RT-PCR data by geometric averaging of multiple internal control genes. Genome Biol 3 2002; research0034.0031. [CrossRef]

15. Leclerc S, Wilkinson KJ. Bioaccumulation of nanosilver by Chlamydomonas reinhardtii- Nanoparticle or the free ion? Environ Sci Technol 2014; 48(1):358-64. [CrossRef]

16. Rajput V, Minkina T, Sushkova S, Behal A, Maksimov A, Blicharska $\mathrm{E}$, et al. $\mathrm{ZnO}$ and $\mathrm{CuO}$ nanoparticles: a threat to soil organisms, plants, and human health. Environ Geochem Health 2020; 42(1): 147-58. [CrossRef]

17. Jin Y, Fan X, Li X, Zhang Z, Sun L, Fu Z, et al. Distinct physiological and molecular responses in Arabidopsis thaliana exposed to aluminum oxide nanoparticles and ionic aluminum. Environ Pollut 2017; 228: 517-27. [CrossRef]
18. Jiang J, Pi J, Cai J. The advancing of zinc oxide nanoparticles for biomedical applications. Bioinorg Chem Appl 2018; 5: 1062562. [CrossRef]

19. Stampoulis D, Sinha SK, White JC. Assay-dependent phytotoxicity of nanoparticles to plants. Environ Sci Technol 2009; 43(24): 94739. [CrossRef]

20. Kumar S, Patra AK, Datta SC, Rosin KG, Purakayastha TJ. Phytotoxicity of nanoparticles to seed germination of plants. Int J of Adv Res 2015; 3(3): 854-65.

21. Lee CW, Mahendra YS, Zodrow YK, Li YD, Tsai YYC, Braam J. Developmental phytotoxicity of metal oxide nanoparticles to Arabidopsis thaliana. Environ Toxicol Chem 2010; 29: 669-75. [CrossRef]

22. Boonyanitipong P, Kumar P, Kositsup B, Baruah S, Dutta J. Effects of zinc oxide nanoparticles on roots of rice Oryza Sativa L. Int Conf Environ BioSci 2011; 21: 172-6.

23. Akdemir $\mathrm{H}$. Evaluation of transcription factor and aquaporin gene expressions in response to $\mathrm{Al}_{2} \mathrm{O}_{3}$ and $\mathrm{ZnO}$ nanoparticles during barley germination, Plant Physiol Biochem 2021; 166: 466-76. [CrossRef]

24. Ma X, Geisler-Lee J, Deng Y, Kolmakov A. Interactions between engineered nanoparticles (ENPs) and plants: Phytotoxicity, uptake and accumulation. Sci Total Environ 2010; 408: 3053-61. [CrossRef]

25. Schwab F, Zhai G, Kern M, Turner A, Schnoor JL, Wiesner MR. Barriers, pathways and processes for uptake, translocation and accumulation of nanomaterials in plants - Critical review. Nanotoxicology 2016; 10(3): 257-78. [CrossRef]

26. Navarro E, Piccapietra F, Wagner B, Marconi F, Kaegi R, Odzak N, et al. Toxicity of silver nanoparticles to Chlamydomonas reinhardtii. Environ Sci Technol 2008; 42(23): 8959-64. [CrossRef]

27. Cota Ruiz K, Delgado Rios M, Martinez-Martinez A, NunezGastelum JA, Peralta Videa JR, Gardea Torresdey JL. Current findings on terrestrial plants - Engineered nanomaterial interactions: Are plants capable of phytoremediating nanomaterials from soil? Curr Opin Environ Sci Health 2018; 6: 9-15. [CrossRef]

28. Choi DW, Zhu B, Close TJ. The barley (Hordeum vulgare L.) dehydrin multigene family: sequences, allele types, chromosome assignments, and expression characteristics of 11 Dhn genes of cv. Dicktoo. Theor Appl Genet 1999; 98: 1234-47. [CrossRef]

29. Khodakovskaya MV, de Silva K, Nedosekin DA, Dervishi E, Biris AS, Shashkov EV et al. Complex genetic, photothermal, and photoacoustic analysis of nanoparticle-plant interactions. Proc Natl Acad Sci USA 2011; 108(3): 1028-33. [CrossRef]

30. Gitto A, Fricke W. Zinc treatment of hydroponically grown barley plants causes a reduction in root and cell hydraulic conductivity and isoform-dependent decrease in aquaporin gene expression. Physiol Plant 2018; 164: 176-90. [CrossRef] 